\title{
Pulmonary effects of acute exposure to nitrous fumes
}

\author{
G. R. JONES, A. T. PROUDFOOT, and J. I. HA L L \\ City Hospital and Royal Infirmary, Edinburgh
}

Four cases of poisoning by nitrous fumes are reported. Three patients presented with pulmonary oedema, and one of these progressed to the phase of bronchiolitis obliterans ; the fourth patient presented with the clinical features of bronchiolitis obliterans. Pulmonary function studies in both phases showed a predominantly restrictive pattern of ventilatory abnormality with a tendency to hypoxaemia, hypocapnia, and reduced transfer factor. Complete recovery followed prompt treatment with corticosteroids. It is emphasized that three of these four accidents were preventable.

The oxides of nitrogen have been incriminated as the main cause of the pulmonary disease which follows exposure to fumes from slow burning nitrocellulose $x$-ray film (Nichols, 1930), the use of acetylene welders in confined spaces (Lindquist, 1944 ; Norwood et al., 1966), detonation of certain types of explosives (Becklake, Goldman, Bosman, and Freed, 1957 ; Müller, 1969), and decomposing silage (Grayson, 1956; Lowry and Schuman, 1956). We report a further four cases in order to increase awareness of this continuing industrial hazard, to comment on the impairment of pulmonary function produced by acute exposure, and to discuss treatment.

\section{METHODS}

Ventilatory capacity was measured using either a Gaensler spirometer or Vitalograph ; predicted normal values were taken from Cotes (1968). Lung volumes were measured by the method of Bates and Christie (1950) with minor modifications; predicted normal values were those of Needham, Rogan, and McDonald (1954). Transfer factor for carbon monoxide was measured by the single breath method (Cotes, 1968), except in case 3 where the steady state method (MacNamara, Prime, and Sinclair, 1959) was used ; predicted normal values were taken from Bates, Macklem, and Christie (1971). Arterial $\mathrm{Po}_{2}$ was measured with a Clark electrode, $\mathrm{PaCO}_{2}$ with a Severinghaus electrode, and arterial pH with an Astrup electrode (Radiometer, Copenhagen); the predicted normal values for age were those of Raine and Bishop (1963). The alveolar-arterial oxygen difference was estimated by the method of Riley, Cournand, and Donald (1951); the predicted normal values were taken from Raine and Bishop (1963). Arterial oxygen saturation was measured using the haemoreflector (Zijlstra and Mook, 1962), and where indicated in the tables the $\mathrm{PaO}_{2}$ has been derived from the $\mathrm{pH}$ and $\mathrm{SaO}_{2}$ using the data of Dill, Edwards, and Consolazio (1937).

\section{CASE REPORTS}

CASE 1 While removing paint with an oxyacetylene burner inside a poorly ventilated fuel tank, a 35-yearold shipyard worker developed stabbing central chest pain which radiated through to the back, profuse sweating, and marked breathlessness. On admission to the coronary care unit he was mildly distressed but six hours later became orthopnoeic. Physical examination revealed coarse crepitations throughout both lungs. The heart rate was $110 / \mathrm{min}$ and blood pressure $140 / 80 \mathrm{mmHg}$. An electrocardiogram (ECG) showed sinus tachycardia and a chest radiograph was normal.

A diagnosis of toxic alveolitis was made and treatment was begun with oxygen, hydrocortisone, 100 $\mathrm{mg}$ intramuscularly, and prednisolone, $40 \mathrm{mg}$, and ampicillin, $2 \mathrm{~g}$, daily by mouth. An hour later there was symptomatic improvement in his breathlessness and within two days the crepitations had disappeared. However, his sensation of chest tightness persisted.

Investigations (Table I) indicated a restrictive ventilatory pattern with hypoxaemia and alveolar hyperventilation. There was no impairment of transfer factor. The initial white blood count was $11,700 / \mathrm{mm}^{3}$

T A B L E I

INVESTIGATIONS IN CASE 1

\begin{tabular}{|c|c|c|c|c|c|c|}
\hline & \multirow{2}{*}{ Predicted \pm SD } & \multicolumn{5}{|c|}{ Days after Exposure } \\
\hline & & 1 & 3 & 5 & 8 & 24 \\
\hline $\begin{array}{l}\text { FEV }_{1}(1 ., \text { BTPS }) \\
\text { FVC (1., BTPS) } \\
\text { FEV }_{1} / \text { FVC }(\%)\end{array}$ & $\begin{array}{r}3.2 \pm 0.5 \\
4.1 \pm 0.6 \\
79.0 \pm 7.0\end{array}$ & $\begin{array}{r}2 \cdot 0 \\
2 \cdot 2 \\
88 \cdot 0\end{array}$ & & & $\begin{array}{r}3 \cdot 9 \\
4 \cdot 6 \\
83 \cdot 0\end{array}$ & $\begin{array}{r}3.9 \\
4 \cdot 8 \\
81 \cdot 0\end{array}$ \\
\hline$\underset{(\mathrm{ml} / \mathrm{min} / \mathrm{mmHg})}{\text { TF (SB) }}$ & $28 \pm 5$ & \multicolumn{4}{|c|}{33.0} & $30 \cdot 0$ \\
\hline $\begin{array}{l}\mathrm{PaO}_{2}(\mathrm{mmHg}) \\
\mathrm{PaCO}_{2}(\mathrm{mmHg}) \\
\mathrm{pH}\end{array}$ & $\begin{array}{c}95 \cdot 0 \pm 7 \cdot 0 \\
36 \cdot 0-44 \cdot 0 \\
7 \cdot 36-7 \cdot 44\end{array}$ & $\begin{array}{l}65 \cdot 0 \\
28 \cdot 0 \\
7 \cdot 47\end{array}$ & & $\begin{array}{l}70 \cdot 0 \\
25 \cdot 0 \\
7 \cdot 46\end{array}$ & & \\
\hline
\end{tabular}


(88\% neutrophils). There was no enzyme or ECG evidence of myocardial infarction.

The dose of prednisolone was gradually reduced and he was discharged after 10 days on a maintenance dose of $10 \mathrm{mg}$ daily. Ampicillin was discontinued before discharge from hospital. Three weeks after exposure he was free of symptoms; ventilatory capacity had returned to normal and an ECG before and after exercise was normal.

CASE 2 A 35-year-old shipwright was exposed to fumes while using an oxyacetylene burner in the same fuel tank a few days later. After 20 minutes he began to sweat profusely and became aware of tightness in his chest; both symptoms were relieved by resting in the open air. After a further 10 minutes' exposure he had to stop work because he felt ill and became breathless with a cough productive of copious yellow sputum.

On admission to hospital two hours after exposure, he was distressed, orthopnoeic, and cyanosed and had cold, clammy extremities. The heart rate was $110 / \mathrm{min}$, blood pressure $120 / 80 \mathrm{mmHg}$, and respiratory rate $40 / \mathrm{min}$. Auscultation of the chest revealed widespread fine and coarse crepitations.

The chest radiograph showed numerous ill-defined, confluent nodular opacities throughout both lungs. Upper lobe vessels were prominent but there were no septal lines and the heart size was normal. The ECG confirmed a sinus tachycardia.

Treatment was started immediately with oxygen and intravenous hydrocortisone $(800 \mathrm{mg})$, together with oral prednisolone (60 mg daily) and ampicillin ( $2 \mathrm{~g}$ daily). Digoxin and frusemide were also given. Within six hours there was marked clinical improvement, and after 48 hours few crepitations remained though rhonchi were heard over both lungs. On the fifth day radiographic clearing of the pulmonary oedema was complete. Prednisolone was withdrawn over four weeks, and ampicillin was stopped after two weeks.

The white cell count on admission was $20,500 / \mathrm{mm}^{3}$ (91\% neutrophils). No pathogenic bacteria were isolated from the sputum. Respiratory function tests (Table II) showed evidence of airway obstruction though the reduction of total lung capacity with a

\section{T A B LE II}

INVESTIGATIONS IN CASE 2

\begin{tabular}{|c|c|c|c|c|c|}
\hline & \multirow{2}{*}{ Predicted $\pm S D$} & \multicolumn{4}{|c|}{ Days after Exposure } \\
\hline & & 3 & 6 & 13 & 270 \\
\hline $\begin{array}{l}\text { FEV }_{1}(1 ., \text { BTPS) } \\
\text { FVC }(1 ., \text { BTPS) } \\
\text { FEV } 1 / \text { FVC }(\%) \\
\text { TLC (1., ATPS) } \\
\text { FRC (1., ATPS) } \\
\text { RV (l., ATPS) } \\
\text { RV/TLC }(\%)\end{array}$ & $\begin{array}{r}3 \cdot 5 \pm 0 \cdot 5 \\
4 \cdot 5 \pm 0 \cdot 6 \\
79 \cdot 0 \pm 7 \cdot 0 \\
6 \cdot 2 \pm 0.9 \\
3 \cdot 3 \pm 0 \cdot 6 \\
2 \cdot 0 \pm 0 \cdot 4 \\
32 \cdot 0 \pm 5 \cdot 0\end{array}$ & $\begin{array}{c}0 \cdot 72 \\
1 \cdot 9 \\
38 \cdot 0 \\
4 \cdot 8 \\
3 \cdot 0 \\
2 \cdot 7 \\
56 \cdot 0\end{array}$ & $\begin{array}{r}1 \cdot 7 \\
3 \cdot 0 \\
57 \cdot 0 \\
- \\
- \\
-\end{array}$ & $\begin{array}{l}2 \cdot 9 \\
4 \cdot 3 \\
67 \cdot 0 \\
- \\
- \\
-\end{array}$ & $\begin{array}{r}2 \cdot 8 \\
4 \cdot 3 \\
65 \cdot 0 \\
6 \cdot 2 \\
3 \cdot 3 \\
2 \cdot 5 \\
40 \cdot 0\end{array}$ \\
\hline $\begin{array}{l}\text { TF (SB) } \\
(\mathrm{ml} / \mathrm{min} / \mathrm{mmHg})\end{array}$ & $30 \cdot 0 \pm 5.0$ & $17 \cdot 0$ & $24 \cdot 0$ & $31 \cdot 0$ & $39 \cdot 0$ \\
\hline $\begin{array}{l}\mathrm{PaO}_{2}(\mathrm{mmHg}) \\
\mathrm{PaCO}_{2}(\mathrm{mmHg}) \\
\mathrm{pH}\end{array}$ & $\begin{array}{c}95 \cdot 0 \pm 7 \cdot 0 \\
36 \cdot 0-44 \cdot 0 \\
7 \cdot 36-7 \cdot 44\end{array}$ & $\begin{array}{c}55 \cdot 0 \\
45 \cdot 0 \\
7 \cdot 43\end{array}$ & E & $\overline{-}$ & E \\
\hline
\end{tabular}

normal functional residual capacity suggested additional restrictive factor. Moderate hypoxaem was also present and the transfer factor was reduce्ws:

CASE 3 A healthy 20-year-old man with no previo history of respiratory disease was exposed to nitrogen dioxide for about 15 minutes after a leak developed at the chemical plant where he was employed. The subsequent illness had two phases.

First phase Three hours after exposure he develope a dry, irritating cough which was later productive of yellowish-brown sputum and associated with wheezex Breathlessness was not prominent until 20 hours latere His general practitioner diagnosed pulmonary oedema but despite treatment with diuretics and penicilli the breathlessness became worse and the patient ws referred to hospital.

On admission he was orthopnoeic and had central cyanosis and an audible wheeze. The respiratory ra was $68 / \mathrm{min}$, heart rate $140 / \mathrm{min}$, and blood pressue $90 / 30 \mathrm{mmHg}$. High-pitched rhonchi and numerow fine crepitations were present throughout both lungst There was marked right subcostal tenderness due to an enlarged smooth liver, the edge of which was palpable $5 \mathrm{~cm}$ below the right costal margin.

The chest radiograph showed opacities compatib with a diagnosis of pulmonary oedema; the ECE showed a sinus tachycardia. The white cell count was $16,800 / \mathrm{mm}^{3}$ ( $82 \%$ neutrophils). Arterial blood ge analysis (Table III) showed hypoxaemia and evidence of mild hyperventilation.

Oxygen was given together with aminophylline $0.5 \mathrm{~g}$, digoxin, $1.0 \mathrm{mg}$, and frusemide, $20 \mathrm{mg}$ intra venously, and digoxin was continued by mout Twelve hours later his general condition was un changed. Hydrocortisone (100 mg intravenously) was given and he started oral prednisolone $(60 \mathrm{mg}$ daily Over the next four days there was steady clinical improvement, and a chest radiograph on the fifth daf showed marked clearing of the diffuse pulmonat. opacities. At this stage the results of ventilatorg function tests were normal but the carbon monoxide transfer factor was reduced.

By the eighth day clinical examination was norma and the $\mathrm{PaO}_{2}$ had improved, though the alveolato arterial oxygen difference was increased. The patient was then discharged taking prednisolone $15 \mathrm{mg}$ dails At review on the fourteenth day he felt well, though still breathless on moderate exertion; the chest radiog graph was normal, and the dose of prednisolone wass further reduced to $10 \mathrm{mg}$ daily.

Second phase On the seventeenth day after exposufe to the gas, while still on $10 \mathrm{mg}$ prednisolone daily, th patient became unwell with headache, tiredness and sweating, aching pains in the abdomen, back and thighs, and increased breathlessness. On the twentiet day he had a rigor and the irritating unproductive cough returned.

On readmission to hospital breathlessness was les? marked than on the first occasion, though centrag cyanosis was present and fine crepitations were agaig 
T A B LE III

INVESTIGATIONS IN CASE 3

\begin{tabular}{|c|c|c|c|c|c|c|c|c|c|c|c|c|}
\hline & & \multirow{2}{*}{ Predicted \pm SD } & \multicolumn{8}{|c|}{ Days after Exposure } & \multirow[b]{2}{*}{85} & \multirow[b]{2}{*}{120} \\
\hline & & & 1 & 6 & 8 & 22 & 25 & 30 & 41 & 55 & & \\
\hline $\begin{array}{l}\text { FEV }_{1} \\
\text { FVC } \\
\text { FEV } / \text { FVC } \\
\text { TLC } \\
\text { FRC } \\
\text { RV } \\
\text { RV/TLC }\end{array}$ & $\begin{array}{l}\text { (1,, BTPS) } \\
(1 ., \text { BTPS) } \\
(\%) \\
(1 ., \text { ATPS) } \\
(1 ., \text { ATPS) } \\
(1 ., \text { ATPS) } \\
(\%)\end{array}$ & $\begin{array}{r}4 \cdot 0 \pm 0.5 \\
5 \cdot 0 \pm 0.6 \\
80.0 \pm 7.0 \\
6.7 \pm 0.9 \\
3.4 \pm 0.6 \\
1.8 \pm 0.4 \\
26.0 \pm 5.0\end{array}$ & $\begin{array}{l}z \\
z \\
z \\
z\end{array}$ & $\begin{array}{r}3 \cdot 8 \\
4 \cdot 9 \\
78 \cdot 0 \\
6 \cdot 2 \\
2 \cdot 4 \\
1 \cdot 2 \\
20 \cdot 0\end{array}$ & $\begin{array}{l}z \\
z \\
z\end{array}$ & $\begin{array}{r}2 \cdot 6 \\
3 \cdot 6 \\
71 \cdot 0 \\
5 \cdot 0 \\
2 \cdot 5 \\
1 \cdot 3 \\
27 \cdot 0\end{array}$ & $\begin{array}{r}2 \cdot 8 \\
3 \cdot 6 \\
78 \cdot 0 \\
- \\
= \\
-\end{array}$ & $\begin{array}{r}3 \cdot 4 \\
4 \cdot 3 \\
79 \cdot 0 \\
- \\
- \\
-\end{array}$ & $\begin{array}{r}3 \cdot 5 \\
4 \cdot 5 \\
78 \cdot 0 \\
= \\
= \\
=\end{array}$ & $\begin{array}{r}4 \cdot 1 \\
4 \cdot 9 \\
84 \cdot 0 \\
= \\
=\end{array}$ & $\begin{array}{r}3 \cdot 9 \\
4 \cdot 8 \\
81 \cdot 0 \\
- \\
-\end{array}$ & $\begin{array}{r}3 \cdot 8 \\
5 \cdot 0 \\
76 \cdot 0 \\
6 \cdot 2 \\
1 \cdot 9 \\
1 \cdot 3 \\
20 \cdot 0\end{array}$ \\
\hline $\overrightarrow{\mathrm{TF}}(\mathrm{SS})$ & $(\mathrm{ml} / \mathrm{min} / \mathrm{mmHg})$ & $>24$ & - & $12 \cdot 0$ & 一 & $10 \cdot 0$ & 一 & $12 \cdot 0$ & $14 \cdot 0$ & - & - & $18 \cdot 0$ \\
\hline $\begin{array}{l}\mathrm{PaO}_{2} \\
\mathrm{SaO}_{2} \\
\left.\mathrm{P}_{2}-\mathrm{A}\right) \mathrm{O}_{2} \\
\mathrm{PaCO}_{2} \\
\text { pH }\end{array}$ & $\begin{array}{l}(\mathrm{mmHg}) \\
(\%) \\
(\mathrm{mmHg}) \\
(\mathrm{mmHg})\end{array}$ & $\begin{array}{c}99.0 \pm 7.0 \\
>95 \\
3 \cdot 0 \pm 6.0 \\
36.0 \pm 44.0 \\
7 \cdot 36-7.44\end{array}$ & $\begin{array}{c}46 \cdot 0^{1} \\
80 \cdot 0 \\
-32 \cdot 0 \\
7 \cdot 40\end{array}$ & $\begin{array}{l}= \\
=\end{array}$ & $\begin{array}{c}76 \cdot 0 \\
94 \cdot 0 \\
39 \cdot 0 \\
31 \cdot 0 \\
7 \cdot 42\end{array}$ & $\begin{array}{c}53 \cdot 0 \\
88 \cdot 0 \\
61 \cdot 0 \\
26 \cdot 0 \\
7 \cdot 46\end{array}$ & $\begin{array}{l}z \\
z\end{array}$ & $\begin{array}{l}- \\
z \\
z\end{array}$ & E & $\begin{array}{l}= \\
=\end{array}$ & $\begin{array}{l}= \\
=\end{array}$ & $\begin{array}{c}89 \cdot 0 \\
96 \cdot 0 \\
16 \cdot 0 \\
34 \cdot 0 \\
7 \cdot 40\end{array}$ \\
\hline
\end{tabular}

${ }^{1}$ Derived (see text).

heard over the lower two-thirds of both lungs. Miliary opacities were now present throughout both lungs on the chest radiograph.

A second rigor associated with a temperature of $39.2^{\circ} \mathrm{C}$ occurred the same evening despite an increase of prednisolone to $60 \mathrm{mg}$ daily. Thereafter all symptoms slowly subsided and radiographic clearing was complete 48 days after exposure.

Lung function tests on this occasion (Table III) showed a dominantly restrictive ventilatory abnormality with more marked hypoxaemia and hyperventilation. The alveolar-arterial oxygen difference was greatly increased and the carbon monoxide transfer factor was reduced. With the exception of the alveolar-arterial oxygen difference, which was still increased, these measurements became normal within four months of exposure to the gas.

CASE 4 A fit 46-year-old coal miner inhaled nitrous fumes after shot firing at the coal face. The only immediate effect was a non-productive cough which partly subsided the next day but subsequently recurred along with shortness of breath. Three weeks after exposure he was admitted to hospital with a three-day history of purulent blood-streaked sputum, sudden worsening of dyspnoea, generalized muscle pains, and chest discomfort.

His general condition on admission was poor and deteriorated further, with a pyrexia of $38.3^{\circ} \mathrm{C}$, central cyanosis, sweating, a sinus tachycardia of $110 / \mathrm{min}$, and the development of coarse crepitations throughout both lungs. The respiratory rate was $40 / \mathrm{min}$. The chest radiograph showed miliary opacities throughout both lungs, with confluence in the lower zones.

Treatment with oxygen, prednisolone, $60 \mathrm{mg}$, and ampicillin, $2 \mathrm{~g}$, daily by mouth resulted in substantial clinical improvement within 24 hours, and after 12 days the chest radiograph was normal. Ampicillin was continued for three weeks, while the dose of prednisolone was tailed off over six weeks.

The white blood count on admission was 15,700 / $\mathrm{mm}^{3}$ (75\% neutrophils). No pathogenic bacteria were cultured from the sputum. Pulmonary function tests (Table IV) in the early stages showed evidence of airways obstruction with hypoxaemia and slight hyperventilation. Later in the course of the illness the carbon monoxide transfer factor rose but did not return to normal for over two months, although ventilatory function tests reached predicted normal values sooner.

TA B LE IV

INVESTIGATIONS IN CASE 4

\begin{tabular}{|c|c|c|c|c|c|c|c|c|c|c|c|c|}
\hline & & \multirow{2}{*}{ Predicted \pm SD } & \multicolumn{10}{|c|}{ Days after Exposure } \\
\hline & & & 21 & 22 & 23 & 27 & 28 & 37 & 45 & 72 & 274 & 330 \\
\hline $\begin{array}{l}\text { FEV } \\
\text { FVC } \\
\text { FEV } / \text { FVC } \\
\text { TLC } \\
\text { FRC } \\
\text { RV } \\
\text { RV/TLC }\end{array}$ & $\begin{array}{l}\text { (1., BTPS) } \\
(1 ., \text { BTPS) } \\
(\%) \\
(1 ., \text { ATPS) } \\
(1 ., \text { ATPS) } \\
(1 ., \text { ATPS) } \\
(\%)\end{array}$ & $\begin{array}{r}3.5 \pm 0.5 \\
4.5 \pm 0.6 \\
75.0 \pm 7.0 \\
6.4 \pm 0.9 \\
3.3 \pm 0.6 \\
2.2 \pm 0.4 \\
34.0 \pm 5.0\end{array}$ & $\begin{array}{l}= \\
z \\
z\end{array}$ & $\begin{array}{r}1 \cdot 4 \\
2 \cdot 2 \\
64 \cdot 0 \\
= \\
= \\
-\end{array}$ & $\begin{array}{l}z \\
z \\
z\end{array}$ & $\begin{array}{r}1 \cdot 4 \\
2 \cdot 5 \\
56 \cdot 0 \\
= \\
=\end{array}$ & $\begin{array}{l}= \\
= \\
=\end{array}$ & $\begin{array}{r}2 \cdot 6 \\
4 \cdot 3 \\
60 \cdot 0 \\
6 \cdot 8 \\
4 \cdot 1 \\
2 \cdot 5 \\
37 \cdot 0\end{array}$ & $\begin{array}{r}2 \cdot 7 \\
4 \cdot 7 \\
57 \cdot 0 \\
6 \cdot 6 \\
3 \cdot 6 \\
2 \cdot 0 \\
30 \cdot 0\end{array}$ & $\begin{array}{r}3 \cdot 6 \\
4 \cdot 8 \\
74 \cdot 0 \\
6 \cdot 4 \\
3 \cdot 3 \\
1 \cdot 2 \\
19 \cdot 0\end{array}$ & $\begin{array}{r}3 \cdot 4 \\
4 \cdot 4 \\
78 \cdot 0 \\
6 \cdot 8 \\
3 \cdot 2 \\
1 \cdot 6 \\
24 \cdot 0\end{array}$ & $\begin{array}{r}3 \cdot 7 \\
4 \cdot 9 \\
76 \cdot 0 \\
6 \cdot 7 \\
3 \cdot 8 \\
2 \cdot 0 \\
30 \cdot 0\end{array}$ \\
\hline TF (SB) & $(\mathrm{ml} / \mathrm{min} / \mathrm{mmHg})$ & $30 \pm 5$ & - & - & - & - & - & $16 \cdot 0$ & $19 \cdot 0$ & $21 \cdot 0$ & $30 \cdot 0$ & $26 \cdot 0$ \\
\hline $\begin{array}{l}\mathrm{PaO}_{2} \\
\mathrm{SaO}_{2} \\
\mathrm{PaCO}_{\mathbf{2}} \\
\text { pH }\end{array}$ & $\begin{array}{l}(\mathrm{mmHg}) \\
(\%) \\
(\mathrm{mmHg})\end{array}$ & $\begin{array}{c}93.0 \pm 7 \cdot 0 \\
>95 \\
36 \cdot 0-44.0 \\
7 \cdot 36-7 \cdot 44\end{array}$ & $\begin{array}{c}60 \cdot 0^{1} \\
89 \cdot 0 \\
30 \cdot 0 \\
7 \cdot 39\end{array}$ & E & $\begin{array}{c}33 \cdot 0^{1} \\
61 \cdot 0 \\
35 \cdot 0 \\
7 \cdot 35\end{array}$ & E & $\begin{array}{c}39 \cdot 0^{1} \\
70 \cdot 0 \\
44 \cdot 0 \\
7 \cdot 36\end{array}$ & $\bar{z}$ & $\bar{z}$ & 二 & E & $\begin{array}{c}82 \cdot 0 \\
97 \cdot 0 \\
39 \cdot 0 \\
7 \cdot 39\end{array}$ \\
\hline
\end{tabular}

${ }^{1}$ Derived (see text). 


\section{COMMENT}

There is no doubt that case 3 was poisoned by nitrous fumes alone and this is probably true also of case 4 as nitrous fumes are the most important product arising from shotfiring underground (Elliott, 1972). While the use of oxyacetylene equipment in confined spaces undoubtedly produces high concentrations of nitrous fumes (Lindqvist, 1944 ; Norwood et al., 1966), which are generally accepted as being the cause of the ensuing pulmonary disease, other harmful respirable substances may be formed (Crofton and Douglas, 1969). Although it is not possible to prove in retrospect, cases 1 and 2 might also have been exposed to ozone, phosgene, irritating fluorides, or the fumes of zinc, copper, cadmium or lead.

Nitrous fumes comprise varying concentrations of the five oxides of nitrogen, the most toxic of which is nitrogen dioxide. The first report of this type of poisoning has been attributed to Desgranges in 1804 (Van Mechelen and Prignot, 1965). The cases of poisoning which we have reported illustrate the various clinical presentations and the biphasic character of the pulmonary response to these gases. The first stage is one of acute pulmonary oedema (cases 1 to 3 ), the onset of which may be delayed up to 36 hours from the time of exposure. Breathlessness is often severe while central cyanosis, sinus tachycardia, rhonchi, and crepitations are commonly present. In common with pulmonary oedema from other causes, there is hypoxaemia which may be severe (Bates et al., 1971) and variable hyperventilation. A restrictive pattern of ventilatory abnormality occurred in cases 1 and 3, whereas airway obstruction was present in case 2 . The reason for this variation in response is uncertain ; case 2 did not give a history of previous respiratory illness though he may have had mild chronic bronchitis caused either by cigarette smoking or by chronic exposure to noxious fumes at his work (Crofton and Douglas, 1969). A polymorph leucocytosis was present in every patient and this has been noted previously (Bates et al., 1971).

Death may occur in the first phase but some patients, even without treatment, will survive. In these patients symptoms may partially remit for a period of several days only to recur (case 3 ). On the other hand, the immediate effects of exposure may not be serious and the patient may present for the first time in the second phase, two to six weeks after exposure (case 4). This phase is frequently ushered in by rigors, pyrexia, recurrence of cough, severe breathlessness, and cyanosis. Chest radiographs characteristically show miliary mottling throughout the lungs (cases 3 and 4), while histological examination of lung obtained at biopsy or necropsy suggests that these opacities are due to an obliterating bronchiolitis (McAdams, 1955).

The presence of these lesions is associated with a reduction of all lung volumes and a predominantly restrictive pattern of ventilatory abnormality. This was so in cases 3 and 4 in whom there were also a reduced carbon monoxide transfer factor, hypoxaemia, and hypocapnia. Clinical improvement is paralleled by improvement in these parameters and when measurements of transfer factor are not possible serial measurements of forced expiratory volume in one second and forced vital capacity will provide a useful guide to the efficacy of treatment. Our observations on pulmonary function in the phase of obliterating bronchiolitis confirm those of Moskowitz, Lyons, and Cottle (1964) on a patient with silo-filler's lung disease. Lépine and Soucy (1962) found similar abnormalities in four patients within three or four weeks of exposure to nitrous fumes though the exact nature of the lung damage at the time of study was not specified. On the other hand, Delaney, Schmidt, and Stroebel (1956) found pulmonary function to be normal in a patient recovering from bronchiolitis.

A review of the literature has revealed no established policy for the treatment of poisoning by nitrous fumes. High concentrations of oxygen are clearly essential but it was generally agreed by earlier authors (Nichols, 1930; Lowry and Schuman, 1956) that digoxin, diuretics, bronchodilator drugs, and antibiotics were of little value. Survival from both phases of the illness is possible without treatment, and spontaneous radiographic clearing of miliary opacities has been reported after 26 days (Delaney et al., 1956) and after four months (Cornelius and Betlach, 1960). Because of this and the small total number of reported cases $N$ it is difficult to make any objective assessment of $N$ the place of corticosteroids in treatment. We believe, however, that these drugs may be life- $\omega$ saving in both phases of the disease. The failure of one patient with pulmonary oedema to improve $\stackrel{\varrho}{C}$ until corticosteroids were given is documented $\mathscr{\Phi}$ (Becklake et al., 1957), as is the relapse of one with? bronchiolitis when attempts were made to with- $\frac{0}{0}$ draw these drugs.

Studies of the effect of corticosteroids on pul- $\frac{\Omega}{\Phi}$ monary function in this disease are sparse, but $\varrho$ our results indicate that return to normal is possible. On the other hand, though Becklake and 
her colleagues (1957) obtained prompt and good clinical improvement from pulmonary oedema using corticosteroids, five patients had persistent symptoms, the severity of which correlated well with reductions in maximal breathing capacity and increases in the non-elastic work of breathing. These patients were gold miners employed underground, and could have been exposed to low concentrations of nitrous fumes over a long time. There is no indication that they did not return to the same occupation, as this may be of some importance in view of present-day concepts of the possible role of nitrous fumes in the aetiology of emphysema (Hueter and Fritzhand, 1971).

We emphasize that our four patients were poisoned in well recognized circumstances which were avoidable in three instances. Nitrogen dioxide is, however, used in the synthesis of many chemicals, and industrial accidents of the type reported in case 3 will no doubt continue to occur. It is clear that greater awareness of this hazard is needed, not only with regard to prevention but in order that effective treatment may be started early.

We thank Dr. Chalmers Davidson, Dr. Henry Matthew, and Dr. R. M. Marquis for allowing us to report on their patients, Miss Sylvia Merchant and Mrs. Lynda Scott for technical assistance, and Dr. A. C. Douglas and Dr. G. J. R. McHardy for helpful criticism and advice.

\section{REFERENCES}

Bates, D. V., and Christie, R. V. (1950). Intrapulmonary mixing of helium in health and in emphysema. Clin. Sci., 9, 17.

-, Macklem, P. T., and Christie, R. V. (1971). Respiratory Function in Disease, 2nd ed. Saunders, Philadelphia, London, Toronto.

Becklake, M. R., Goldman, H. I., Bosman, A. R., and Freed, C. C. (1957). The long-term effects of exposure to nitrous fumes. Amer. Rev. Tuberc., 76, 398.

Cornelius, E. A., and Betlach, E. H. (1960). Silo-filler's disease. Radiology, 74, 232.

Cotes, J. E. (1968). Lung Function, 2nd ed. Blackwell, Oxford.
Crofton, J. W., and Douglas, A. C. (1969). Respiratory Diseases, Blackwell, Oxford and Edinburgh.

Delaney, L. T., Schmidt, H. W., and Stroebel, C. F. (1956). Silo-filler's disease. Proc. Mayo Clin., 31, 189.

Dill, D. B., Edwards, H. T., and Consolazio, W. V. (1937). Blood as a physico-chemical system: XI. Man at rest. J. biol. Chem., 118, 635.

Elliott, T. K. (1972). An unusual case of asphyxia in a coalminer following exposure to shotfiring fumes. Practitioner, 208, 794.

Grayson, R. R. (1956). Silage gas poisoning: nitrogen dioxide pneumonia, a new disease in agricultural workers. Ann. intern. Med., 45, 393.

Hueter, F. G., and Fritzhand, M. (1971). Oxidants and lung biochemistry. Arch. intern. Med., 128, 48.

Lépine, C., and Soucy, R. (1962). La bronchopneumopathie d'origine toxique. Un, Méd. Can., 91, 7.

Lindqvist, T. (1944). Nitrous gas poisoning among welders using acetylene flame. Acta med. scand., 118, 210.

Lowry, T., and Schuman, L. M. (1956). Silo-filler's diseasea syndrome caused by nitrogen dioxide. J. Amer. med. Ass., 162, 153.

MacNamara, J., Prime, F. J., and Sinclair, J. D. (1959). An assessment of the steady-state carbon monoxide method of estimating pulmonary diffusing capacity. Thorax, 14, 166.

McAdams, A. J. (1955). Bronchiolitis obliterans. Amer. J. Med., 19, 314.

Moskowitz, R. L., Lyons, H. A., and Cottle, H. R. (1964). Silofiller's disease. Amer. J. Med., 36, 457.

Müller, B. (1969). Nitrogen dioxide intoxication after a mining accident. Respiration, 26, 249.

Needham, C. D., Rogan, M. C., and McDonald, I. (1954). Normal standards for lung volumes, intrapulmonary gas-mixing, and maximum breathing capacity. Thorax, 9, 313.

Nichols, B. H. (1930). The clinical effects of the inhalation of nitrogen dioxide. Amer. J. Roentgenol., 23, 516.

Norwood, W. D., Wisehart, D. E., Earl, C. A., Adley, F. E., and Anderson, D. E. (1966). Nitrogen dioxide poisoning due to metal-cutting with oxyacetylene torch. J. occup. Med., 8, 301.

Raine, J. M., and Bishop, J. M. (1963). A-a difference in $O_{2}$ tension and physiological dead space in normal man. J. appl. Physiol., 18, 284.

Riley, R. L., Cournand, A., and Donald, K. W. (1951). Analysis of factors affecting partial pressures of oxygen and carbon dioxide in gas and blood of lungs: methods. J. appl. Physiol., 4, 102.

Van Mechelen, J., and Prignot, J. (1965). Intoxication collective aux vapeurs rutilantes. Acta tuberc. pneumol. belg., 56, 68.

Zijlstra, W. G., and Mook, G. A. (1962). Medical Reflection Photometry. Van Gorcum, Assen. 